\title{
Academic Dishonesty: Lecturer's Skepticism, Gender, and Experience
}

\author{
Fanji Indra Julian Dini ${ }^{1}$, Amy Fontanella ${ }^{2}$, and Sukartini ${ }^{3}$ \\ \{juliandidini@gmail.com ${ }^{1}, \underline{\text { amyfontanella99@gmail.com² }}$, tiensukartini28@gmail.comc ${ }^{3}$ \}
}

\begin{abstract}
Accounting Departement [Padang State Polytechnic], 081268906655', Accounting Departement [Padang State Polytechnic], 08126760804², Accounting Departement [Padang State Polytechnic], $08126708432^{3}$.
\end{abstract}

\begin{abstract}
This study investigates the effect of the lecturer's skepticism, gender, and experience on students' academic dishonesty. This research was conducted on Padang State Polytechnic lecturers, using survey method in data collection. The results showed that lecturers' skepticism and experience had a positive effect on students' academic dishonesty. This finding consistent with Theories of Planned Behavior (TPB), Organization Theory and the contemporary cognitive theory which holds that skeptical lecturers would be inclined to refrain from the issue of academic dishonesty. These findings contribute to Politeknik Negeri Padang in determining the appropriate policy to overcome student's academic dishonesty.
\end{abstract}

Keywords: Academic dishonesty, skepticism, gender, lecturer's experience

\section{Introduction}

The phenomenon of academic dishonesty in Indonesian educational world is rife. This behavior has been embedded since elementary education up to college. This phenomenon should be noticed because it will impact the quality of education in Indonesia.

Previous studies have addressed the issue of students' academic dishonesty. Some researchers test the determinants of academic dishonesty[1], [2], [3]. The discussion of these factors uses the psychological approach [4] and criminology approach [5]. The importance of understanding the factors that influence this academic dishonesty should also be accompanied by logical thinking on how to overcome it [6], [7], [5], and [8].

Unfair punishment is an important factor in the rise of academic dishonesty behavior. According to [5] there are several methods to reduce student academic dishonesty, such as applying heavier punishment and using more supervisors during the exam. In addition, [8] stated, the weak imposition of sanctions to the perpetrators of academic dishonesty caused the perpetrator to have more room and chances to commit academic dishonesty, furthermore the lack of lecturers' understanding of the importance of sanctions also affected the act of academic dishonesty among students.

The choice of how to deal with academic dishonesty is also crucial. [7] emphasized that the lecturers rarely report cases of academic dishonesty officially and choose to deal with them informally. Lecturers who trust in the process of handling academic dishonesty by institutions prefer formal means in addressing cases of alleged academic dishonesty. While skeptical lecturers tend to refrain from the handling process of suspected academic dishonesty formally [6]. 
The handling of academic dishonesty requires effective strategy and cooperation between institutions and lecturers. Forming an administration system that is run cooperatively would certainly be more effective to reduce even preventing the occurrence of academic dishonesty among students.

This study analyzes the effect of the lecturer's skepticism, gender and lecturer's experiences on student's academic dishonesty. Using the lecturer's of Politeknik Negeri Padang as a research object, this study found that lecturer skepticism and experience had a positive effect on academic dishonesty. This research is expected to contribute to the literature by providing empirical evidence of the influence of lecturer skepticism, gender, and experience on academic dishonesty of students. Furthermore, this research is expected to contribute to Politeknik Negeri Padang in formulating policies related to academic dishonesty of students.

\section{Literature Review and Hypothesis Development}

Previous research found that there were differences in perceptions between lecturers and students concerning academic dishonesty behavior [7]. Students tend to consider academic dishonesty as minor cheating. On the other hand, lecturers and colleges consider academic dishonesty as a major violation category in the academic world.

Lecturer's Skepticism in settling academic dishonesty is also affecting academic dishonesty [7]. Consistent with [7], a study conducted by [6] found that the lecturer's skepticism caused lecturers to tend to allow student's academic dishonesty. This skeptical attitude also causes the lecturers to not see the student cheating behavior as a big problem so that when this behavior arises lecturers tend to allow it.

Organizational theory is a theory that seeks to explain how organizations and people are involved in organization, culture, and environment to achieve their goals. This theory discusses the system, formal organizations, informal organizations, status structures, physical roles and environments [9]. Higher education is an organization that aims to organize a formal education system. Maintaining the campus climate was the responsibility of universities and lecturers [6]. [6] argue that the structure, organization's size, and the purpose of college members as well as the background of academics, have greater potential in the organization's processes and outcomes in handling student's academic dishonesty. Academic dishonesty is one of the zones where the college plays a role in raising the lecturer's awareness of academic dishonesty.

According to [6] skeptical lecturers tend to take informal means to deal with student academic dishonesty. Handling by informal means usually involve directing, giving advice or other persuasive approaches. Moreover, [6] found that lecturers who were not skeptical in dealing with academic dishonesty were more likely to deal with formal means and handle them openly together with colleges. This statement was strengthened by the research conducted by [8] and [5] who found that the weak sanctions system as well as the lack of clarity and strict sanctions given by most lecturers lead to opportunities for students to commit academic dishonesty.

Based on the theory and results of the above researchs, the following hypothesis is formulated:

H1: Skeptical lecturers tend to find fewer academic dishonesty among students.

According to the Sociological Theories of Self-Development, boys and girls have a different moral understanding. Boys tend to have a perspective of justice, with prioritizing rules and laws. On the other hand, girls have a perspective of attention and responsibility. Gilligan explained that the boys were socialized for the work environment, while girls were socialized for the home environment. In accordance with Gilligan's statement, every child who grows up is expected to learn how to behave according to their respective gender [10]. 
Consistent with Gilligan's Theory of Moral Development and Gender, [6] found that female lecturers are more skeptical about college regulations compared to male lecturers in dealing with Academic dishonesty. This means that male lecturers are more obedient to the rules than female lecturers. Female lecturers tend to provide direction, education, and advice in response to student academic dishonesty.

Then based on the literature review and theory above, we formulated the following hypothesis:

H1. Male lecturers tend to find more academic dishonesty among students than female lecturers.

Contemporary cognitive theories view humans as agents who actively accept, use, manipulate, and divert information. We actively think, make plans, solve problems, and take decisions. Humans process information in a certain way through the cognitive structures that are given the term "schema". The structure serves as a framework that can interpret the social experiences we have. The cognition structures may help us achieve alignment with the environment, and help us to compose social reality. The memory system that we have is assumed to consist of countless knowledge structures. In essence, cognitive theories focus on how we process the information that comes from the environment into our mental structure [9].

This view is in line with the research results of Smith and Nolan [1] which found that the lecturer's experience in fulfilling its role as an educator raises the lecturer's negative perception on student's behavior. Lecturers always think about the possibility of students cheating even before other students report an academic dishonesty. It can be concluded that lecturers are processing all information both from their knowledge, environment, and experience as a lecturer so that they have a negative perception regarding the possibility of students doing an academic dishonesty.

Based on contemporary cognitive theories and the results of the above research, the following hypothesis is formulated:

H3. Experienced lecturers tend to find more academic dishonesty among students.

\section{Strategies for Dealing with Student Academic Dishonesty}

According to [6], there are two methods that can be used to prevent academic dishonesty of students through academic sanctions. The first method is a formal method of addressing the problem of student dishonesty by involving college regulations. When violations are detected, lecturers can process them formally. The second method is informal. With this method, the lecturer will provide guidance, advice and persuasive methods to students who have been proven to commit academic dishonesty.

\section{Methodology}

This research is a quantitative study with survey methods. The sample used in the research was all lecturers of Padang State Polytechnic majoring in Accounting, Business Administration and English department. This sampling is backed by uniformity in the method of learning and student characteristics in the 3 majors. In order to collect data, researchers distribute questionnaires conducted online using Google forms deployed via the WhatsApp application. In addition, questionnaires are also distributed directly by visiting lecturers in person. The number of respondents obtained was 92 lecturers or around $90 \%$ of the population.

The research questionnaire being used came from previous research questionnaires [6] and [11]. This research questionnaire consists of several sections. The first section contains information about the respondent, i.e. education level, age, gender, job title, and lecturer experience. The second part contains information regarding the type of academic dishonesty that occurs, the means used in conducting academic dishonesty, and courses that are the object of academic dishonesty. The third, fourth and fifth sections are related to the lecturer's skepticism. This section covers the lecturers' views, feelings, actions and beliefs on policies used in dealing with student's academic dishonesty. 
The research models developed are as follows:

$K J A K=a_{0}+a_{1} S K D S+a_{2} G N D R+a_{3} P G D S+a_{4}$ USIA $+a_{3} J P D S+a_{3} J U D S+e$

Description:

KJAK = Academic dishonesty (Dependent variables)

SKDS = Skepticism (Independent variable)

GNDR = Gender (Independent variable)

PGSD = Lecturer experience (Independent variable)

USIA = Lecturer Age (Control Variable)

JPDS = Lecturer Education Level (Variable Control)

JUDS = Lecturer Department (Variable Control)

e Error

Before distributing the questionnaire to respondents, researchers have conducted a validity and reliability test. In addition to the validity and reliability test, researchers have also tested data normality, heteroscedasticity tests, and multicollinearity tests.

\section{Result and Discussion}

The followings are the results of coefficient of determination test from this study.

Table 1

Coefficient of Determination

\begin{tabular}{|c|c|c|c|c|}
\hline \multicolumn{5}{|c|}{ Model Summary } \\
\hline $\begin{array}{l}\text { Mod } \\
\text { el }\end{array}$ & $\mathrm{R}$ & R Square & $\begin{array}{l}\text { Adjusted R } \\
\text { Square } \\
\end{array}$ & $\begin{array}{l}\text { Std. Error of } \\
\text { the Estimate }\end{array}$ \\
\hline 1 & 0,354 & 0,126 & 0,064 & 2,747 \\
\hline $\begin{array}{l}\text { Inforr } \\
2,1984 \\
\end{array}$ & $\mathrm{n}=9$ & $\mathrm{DL}=1,52$ & $J=1,8016,(4$ & $2,4751,(4-\mathrm{DU})=$ \\
\hline
\end{tabular}

The test results show adjusted $\boldsymbol{R}^{2}$ as 0.064 , this indicates the findings of academic dishonesty, $6.4 \%$ influenced by lecturer skepticism, lecturer gender and lecturer experience.

\section{Hypothesis Testing}

The following are the multiple regression test results of this study.

Table 2

Hypothesis testing results

\begin{tabular}{|c|c|c|c|c|}
\hline \multicolumn{5}{|c|}{$Y=9,933+0,056 \times 1+0,780 \times 2+0,160 \times 3-1,262+1,710+1,174+e$} \\
\hline Variable & Prediction & $\mathrm{B}$ & $\mathrm{T}$ & Sig. \\
\hline (Constant) & & 99,933 & 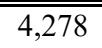 & \\
\hline Skepticism & $\mathrm{H} 1:(+)$ & 0,056 & 1,347 & $0,091^{*}$ \\
\hline Gender & $\mathrm{H} 2:(+)$ & 0,780 & 1,180 & 0,120 \\
\hline Lecturer Experience & H3: $(+)$ & 0,160 & 2,179 & $0,016 * *$ \\
\hline Department & - & 1,174 & 1,860 & $0,033 * *$ \\
\hline Age & - & $-1,262$ & $-1,901$ & $0,030 * *$ \\
\hline Education level & - & 1,710 & 1,704 & $0,046^{* *}$ \\
\hline
\end{tabular}

Information : *sig. $<0,1 * *$; Sig. $<0,05 ; * * *$ sig. $<0,01$

$\mathrm{Y}=$ Academic dishonesty findings, $\mathrm{X} 1=$ lecturer's Skepticism, $\mathrm{X} 2=$ Gender, $\mathrm{X} 3=$ Lecturer Experience

Source: SPSS Test Result 
The table above shows that skepticism of lecturer has a positive effect on the number academic dishonesty findings, then $\mathrm{H} 1$ is accepted. With a significance value of 0.091 , the lecturer's skepticism has a significant effect on the level of academic dishonesty at $\alpha=10 \%$. Gender variables are not proven to affect the findings of academic dishonesty conducted by students.

The last independent variable was teaching experience that positively influenced the academic dishonesty then $\mathrm{H} 3$ is accepted. In addition to independent variables, there are also three control variables, namely lecturer majors, lecturer age and education level.

The results showed that lecturers from Department other than Accounting found more academic dishonesty. Furthermore, the age of lecturers proved negatively influenced the findings of academic dishonesty. On the contrary, the level of education was found to have a positive effect on academic dishonesty.

\section{Discussion}

Skepticism was positively influential in the degree of academic dishonesty found by lecturers. The higher the skepticism that the lecturer has, the fewer academic dishonesty will be encountered. Lecturers tend to consider academic dishonesty as a minor problem. According to the Theory of Planned Behavior, humans are rational and use information that is possible to them systematically. People think of the implications of their actions before they decide to commit or not commit a particular behavior [12]. This skeptical attitude can indicate that the lecturer does not want to engage with the issue of academic dishonesty. This is due to the onset of discomfort or concern for an ungood reputation for dealing with students' academic dishonesty actions.

[6] state that skeptical lecturers will be seen distancing themselves from the administrative process and addressing the case of alleged academic dishonesty more informally. Similarly, theory of modern organizations claim that organizations must be open or related to the environment [13]. In this case, academic dishonesty is one of the zones where the college plays a role in raising the lecturer's awareness of the case of alleged academic dishonesty by students [6].

The first action a lecturer can take in this case is to report academic dishonesty to the college administration section. Oftenly, the absence of direct reports from lecturer as an agent that interacts directly with students, resulting the colleges to not be able to comply with policies and regulations that can restrict academic dishonesty in college students. This will result in higher student academic dishonesty behavior.

The next step is that colleges and lecturers can work together to form an administrative regulatory system to prevent and overcome students' academic dishonesty. In some studies, it was found that students' academic dishonesty can be overcome by lecturers providing strict sanctions [5].This regulatory system can be formed by combining formal and informal administrative systems. This is due to no one can guarantee whether the formal administration system is better than the informal administration system, as well as vice versa. However, it is necessary to remember the regulatory system will work effectively if applied properly and consistently by lecturers. [8] found that the lack of lecturers' understanding of the importance of the sanctions provided also had an effect on dishonesty among students.

Lecturer's experience has a positive effect to the degree of lecturer-found academic dishonesty. It can be concluded that the higher the experience a lecturer has, the more academic dishonesty found. These results are consistent with the results of Smith and Nolan's research [1] in seeing lecturers' perceptions about students' academic dishonesty. Where Smith and Nolan found that lecturers tended to believe students would cheat, in which case lecturers had a negative perception of student behavior even before other students reported the academic dishonesty. This perception is based on the lecturer's experience itself. So with this experience, lecturers become more aware of the results of assignments or student tests to see indications of whether or not there is academic dishonesty done by students in the process.

The results of this research can be explained by contemporary cognitive theory. The Contemporary cognitive theory explains that human beings process information with cognitive structures. This structure serves as a framework that can interpret the social experiences we have. The memory system that we have is assumed to 
consist of countless knowledge structures. In essence, cognitive theories focus on how we process the information that comes from the environment into our mental structure [9].

\section{Conclusion}

Various forms of academic dishonesty were performed by college students ranging from cheating, plagiarism, collaboration and so on with various factors that caused it. The onset of academic honesty among students will create a negative reputation for the college. One step that must be done by lecturers and colleges in preventing or reducing student's academic dishonesty is working cooperatively by forming an effective administration system. However, many of the lecturers are skeptical of the regulatory system in college. Lecturer skepticism causes them to resolve academic dishonesty by using informal means

This study found that lecturer skepticism had a positive effect on the amount of academic dishonesty committed by students. This study also found that more experienced lecturers found more academic dishonesty among students.

This research has several limitations. First, this study is limited to explore the effect of lecturer skepticism, gender and lecturers' experience on academic dishonesty found by lecturers. This research has not perform deeper analysis concerning the impacts and strategies undertaken to overcome students ' academic dishonesty. Future studies are suggested to use mix methods to combine statistical results with qualitative data so that more comprehensive research results could be obtained. Second, related to the research object which was only conducted on lecturers from three departments in Padang State Polytechnic. It is expected that further research to be carried out with various lecturers from various departments in higher education so that research results could be generalized.

\section{Thank-you Note}

Thanks to Miss Ivo, who had given their time and knowledge to the author. Due to the help and support of miss Ivo, this journal can be resolved. Thanks also to the miss Sukartini who has guided the authors to complete this journal. Specials for family and friends who have supported and prayed for authors to be able to resolve this journal. 


\section{References}

[1] B. Hendricks, "Academic Dishonesty: A Study in the Magnitude of and Justifications for Academic Dishonesty Among College Undergraduate and Graduate Students," J. Coll. Student Dev., pp. 212-260, 2004.

[2] I. A. Ghaida, A. Fontanella, and F. Sriyunianti, "PENGARUH FAKTOR INDIVIDUAL DAN SITUASIONAL TERHADAP,” J. Akunt. dan Manag., vol. 1, p. 1, 2018.

[3] R. Mustapha, Z. Hussin, and S. Siraj, “JuKu,” J. Kurikulum Pengajaran Asia Pasifik, no. 2, pp. 1-18, 2017.

[4] E. M. Anderman, "The Effect Of Personal, Classroom, and School Goal Structures On Academic Cheating," vol. 5, pp. 87-106, 2007.

[5] S. W. Tabsh, A. S. Abdelfatah, and H. A. El Kadi, "Engineering students and faculty perceptions of academic dishonesty," vol. 25, no. 4, pp. 378-393, 2017.

[6] C. A. Simon, J. R. Carr, S. M. McCullough, S. J. Morgan, T. Oleson, and M. Ressel, "The other side of Academic Dishonesty: The relationship between faculty scepticism, gender and strategies for managing student academic dishonesty cases," Assess. Eval. High. Educ., vol. 28, no. 2, pp. 193-207, 2003.

[7] T. Kwong, H. M. Ng, M. Kai-Pan, and E. Wong, "Students' and faculty's perception of academic integrity in Hong Kong," Campus-Wide Inf. Syst., vol. 27, no. 5, pp. 341-355, 2010.

[8] I. D. Aprilisanda, I. Yuhertiana, and H. Priono, "Persepsi Dosen Akuntansi Terhadap Praktik Kecurangan Akademik Pada Upn 'Veteran' Jawa Timur (Studi Pada Progdi Akuntansi)," Behav. Account. J., vol. 1, no. 1, pp. 97-110, 2018.

[9] H. Mustafa, "Perilaku Manusia Dalam Perspektif Psikologi Sosial Hasan," J. Adm. bisnis, vol. 7, no. 2, pp. 143-156, 2011.

[10] R. University, Introduction to Socioloty 2e. Houston, Texas: OpenStax, 2017.

[11] R. D. Winardi, A. Mustikarini, and M. A. Anggraeni, "Academic Dishonesty Among Accounting Students: Some Indonesian Evidence,” J. Akunt. dan Keuang. Indones., vol. 14, no. 2, pp. 142-164, 2017.

[12] Z. Achmat, “THEORY OF PLANNED BEHAVIOR, MASIHKAH RELEVAN ?,” pp. 1-26, 1988.

[13] S. Muslamat, "Teori Organisasi," pp. 1-19. 